\title{
Selectivity of Herbicides Applied in Preemergence and Diuron in Postemergence for Sesame
}

\author{
Valdinei Sofiatti (corresponding author) \\ Researcher Embrapa Algodão \\ Palmas, Tocantins, Brazil. Postal code: 77001-048 \\ Tel: 55-63-9847496111_E-mail: valdinei.sofiatti@embrapa.br \\ Augusto GF Costa \\ Researcher Embrapa Algodão \\ Jaguariuna, São Paulo, Brazil. Postal code: 13820-000
}

Sidnei D Cavalieri

Researcher Embrapa Algodão

Sinop, Mato Grosso, Brazil. Postal code: 78550-970

Lucas S Martins

Student Catholic Faculty of Tocantins

Palmas, Tocantins, Brazil. Postal code: 77024-710

\section{Cássio L Pereira}

Student Catholic Faculty of Tocantins

Palmas, Tocantins, Brazil. Postal code: 77024-710

Thiago RB Silva

Student Catholic Faculty of Tocantins

Palmas, Tocantins, Brazil. Postal code: 77024-710 
Vilmar V Clemente

Student Catholic Faculty of Tocantins

Palmas, Tocantins, Brazil. Postal code: 77024-710

Received: September 3, $2021 \quad$ Accepted: October 1, $2021 \quad$ Published: October 9, 2021

doi:10.5296/jas.v9i4.18981

URL: https://doi.org/10.5296/jas.v9i4.18981

\begin{abstract}
The expansion of sesame growth has led to one of the biggest challenges in weed management mainly due to the limited options of selective herbicides for the control of eudicots species. This study aimed to evaluate the selectivity of diuron, s-metolachlor or imazethapyr herbicide treatments in isolation, or in a tank mixture, when applied in preemergence only, or association with diuron herbicide sprayed in postemergence during sesame cultivation. Two experiments were carried out under Brazilian Cerrado conditions. In the first experiment, different doses ( $\mathrm{g}$ $\mathrm{ha}^{-1}$ ) of diuron (500 and 750), s-metolachlor (480 and 960) and imazethapyr (40 and 80) were applied in preemergence in isolation or in a tank mixture. In the second experiment, doses ( $\mathrm{g}$ $\mathrm{ha}^{-1}$ ) of the herbicides diuron (500 and 750) and s-metolachlor (480 and 720) were applied in preemergence isolated or in tank mixture, associated or not with diuron $\left(500 \mathrm{~g} \mathrm{ha}^{-1}\right)$ in postemergence. The results indicated that diuron and s-metolachlor applied in isolation or in combination during preemergence are selective to the sesame crop up to the doses of $750 \mathrm{~g} \mathrm{ha}^{-1}$ and $720 \mathrm{~g} \mathrm{ha}^{-1}$, respectively, and when applied in association with diuron at a dose of $500 \mathrm{~g} \mathrm{ha}^{-1}$ in postemergence are also selective for sesame crop.
\end{abstract}

Keywords: chemical control, diuron, imazethapyr, Sesamum indicum L, s-metolachlor

\title{
1. Introduction
}

Sesame an oilseed crop, which has a high tolerance for water deficiency, is traditionally grown in semiarid regions of the world. In Brazil, this species has been traditionally cultivated by small farmers. Recently, farmers in the Cerrado region began growing sesame between soybean cultivation cycles due to sesame's short cycle and low water demand, ideal characteristics for the subsequent soybean crop cycle.

One of the technical factors to consider when planting crops in large areas is the availability of selective herbicides for the chemical control of weeds. Herbicides are used in pre and postemergence so that weeds do not interfere with the sesame cultivation. Weed competition can results in more than 50\% yield loss (Ambika and Sundari, 2019; Ayesha et al., 2020; Hossain et al., 2020; Lins et al., 2020). Therefore, cultivation must be kept free from infestation until approximately 50 days after sowing (Lins et al., 2019).

In an extensive literature review, Grichar et al., (2011) found that alachlor, diuron, linuron, s-metolachlor, pendimethalin and trifluralin are the main herbicides used in preemergence 
during sesame cultivation. Alachlor is commonly used in several sesame-producing countries, such as Thailand, Honduras, El Salvador and Mexico. Despite research studies confirming the selectivity of alachlor over sesame, some countries do not use it for commercial purposes due to environmental restrictions (Grichar et al, 2011). Most herbicides used in preemergence reduce the germination potential and the height of sesame plants (Grichar et al, 2001a). For instance, incorporation of herbicides of the chemical group of dinitroanilines, such as ethafluoralin and pendimethalin at a depth of 5 to $8 \mathrm{~cm}$ in the pre-planting (IPP) modality reduced the stand and the yield of the crop when compared to incorporation at $2 \mathrm{~cm}$ depth (Grichar and Dotray, 2007). However, the same herbicides provide a low spectrum of eudicots weed control. Nevertheless, Mane et al. (2017) reported that pendimethalin applied in preemergence in combination with one hand weeding at 30 days after sesame emergence was more effective than herbicide application alone. Grichar et al., (2009) also found that the herbicide s-metolachlor $\left(1,440 \mathrm{~g} \mathrm{ha}^{-1}\right)$ caused a stand reduction and phytotoxicity in only one environment among the four evaluated.

The herbicide diuron has stood out as an option for sesame cultivation because of its' effective control over a wide number of weed species and for its selectivity mainly in preemergence. Beltrão et al., (1991) found that a dose of diuron of $1,000 \mathrm{~g} \mathrm{ha}^{-1}$ in preemergence did not reduce the yield of sesame cultivation in the Northeast of Brazil in sandy-loam soil with $0.76 \%$ organic matter (OM). In Nigeria, Wamduda, et al., (2017) also verified the selectivity of diuron at a dose of $500 \mathrm{ha}^{-1}$ applied in preemergence in sandy soil with $83 \%$ sand and $0.7 \%$ OM. Conversely, Grichar et al., (2009) verified that a dose of diuron of $1,120 \mathrm{~g} \mathrm{ha}^{-1}$ in preemergence caused phytointoxication to sesame in an experiment carried out in the Texas highlands (USA) in medium-textured soil with $20 \%$ to $40 \%$ clay and $0.8 \%$ of OM. However, other experiments in that same location and in South Texas, conducted for two consecutive years indicated the selectivity of diuron to the sesame crop. The divergent results regarding the selectivity of this herbicide observed by these researchers could be attributed to differences in doses and soil characteristics. Furthermore, Grichar et al., (2018) found selectivity the herbicide diuron to sesame in postemergence in some locations of their study; suggesting potentially novel uses for this herbicide.

Although there are some herbicide options for use in preemergence in the sesame crop, the greatest difficulty is related to the control of eudicot weed species and also of volunteer soybean in postemergence when the sesame is cultivated in succession to the soybean, because the molecules available on the market have not shown selectivity, causing considerable damage to plants (Grichar et al., 2001b; Grichar et al., 2011; Sperry et al., 2017). The alternative of using full-action herbicides in directed jet, in addition to not effectively controlling the weeds located in the sowing line, presents a risk of sesame intoxication (Grichar et al., 2014). However, there are several ACCase inhibiting herbicides selective for the control of monocotyledonous species of the Poaceae family, (Ambika and Sundari, 2019; Murimwa et al., 2019; Bereta et al., 2021).

Thus, this study evaluated the selectivity of herbicide treatments applied in isolation and in a tank mixture in preemergence, or in combination with the diuron herbicide applied in postemergence of sesame crop. 


\section{Material and Methods}

Two consecutive field experiments were carried out in 2018 and 2019, respectively, in Palmas, Tocantins, Brazil (10 24' 01" S and 48 21' 47" W and $219 \mathrm{~m}$ altitude). The local climate in this region is described as tropical savanna Aw (Köppen) with an annual average temperature of $26.7^{\circ} \mathrm{C}$ and rainfall of $1,760 \mathrm{~mm}$, dry winters and predominantly rainy summers. The soil in the experimental area was as the Dystrophic Red-Yellow Latosol comprised of $280 \mathrm{~g} \mathrm{~kg}^{-1}$ of clay, $120 \mathrm{~g} \mathrm{~kg}^{-1}$ of silt and $600 \mathrm{~g} \mathrm{~kg}^{-1}$ of sand (EMBRAPA, 2018). Before commencing the first experiment, the soil had the following chemical characteristics: $\mathrm{pH}$ in $\mathrm{CaCl}_{2}=5.8 ; \mathrm{Ca}^{2+}$ $=2.14 \mathrm{cmol}_{\mathrm{c}} \mathrm{dm}^{-3} ; \mathrm{Mg}^{2+}=1.56 \mathrm{cmol}_{\mathrm{c}} \mathrm{dm}^{-3} ; \mathrm{H}+\mathrm{Al}=1.9 \mathrm{cmol}_{\mathrm{c}} \mathrm{dm}^{-3} ; \mathrm{V}=65.0 \% ; \mathrm{P}=1.0 \mathrm{mg}$ $\mathrm{dm}^{3} ; \mathrm{K}=60 \mathrm{mg} \mathrm{dm}{ }^{3}$ and organic matter $(\mathrm{OM})=18 \mathrm{~g} \mathrm{~kg}^{-1}$.

The first experiment to assess the selectivity of herbicide doses in preemergence in the sesame crop was installed on February $13^{\text {th }}, 2018$. The second experiment, to evaluate the selectivity of herbicide doses applied in isolation or in a tank mixture in preemergence with or without the herbicide diuron in postemergence, was installed on February $3^{\text {rd }}, 2019$. Precipitation data for the years 2018 and 2019, the period of the two experiments, are presented in Figures 1A and 1B, respectively.

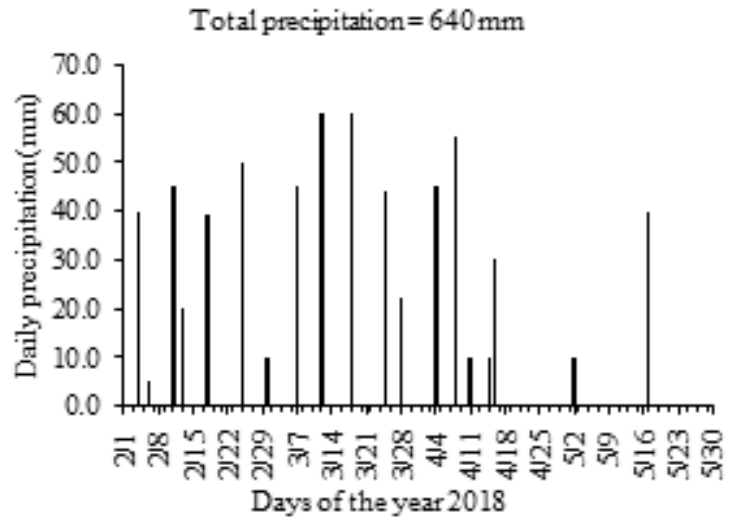

a

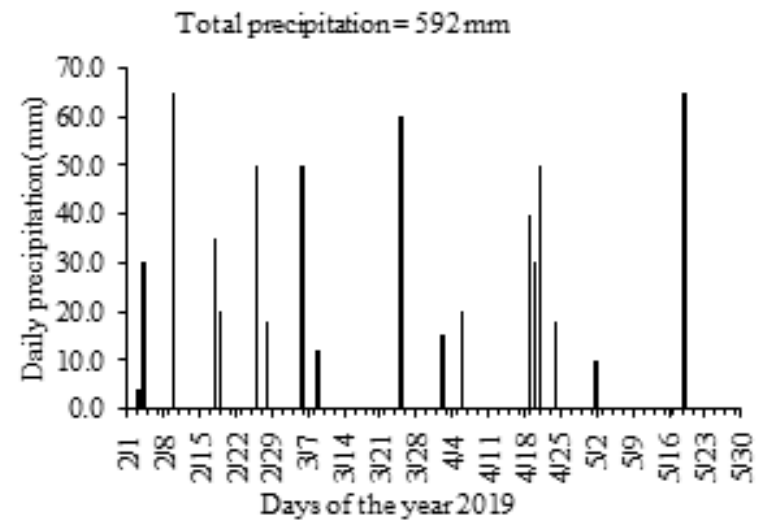

b

Figure 1. Daily rainfall in the years 2018 (a) and 2019 (b) in Palmas, Tocantins, Brazil.

The BRS Anahi cultivar, used in both experiments, was sown with a vacuum seeder fertilizer leaving $0.80 \mathrm{~m}$ between sowing lines with 12 to 15 seeds sown per linear meter. The plots were made up of four lines with four meters long; the two central lines were harvested for yield estimation. At the time of sowing, $180 \mathrm{~kg} \mathrm{ha}^{-1}$ of the Monoammonium Phosphate compost (20-90-00 $\mathrm{kg} \mathrm{NPK} \mathrm{ha}^{-1}$ ) was applied to the soil. Additionally, equal doses of two cover fertilizations totaling $120 \mathrm{~kg} \mathrm{ha}^{-1}$ of urea and $120 \mathrm{~kg} \mathrm{ha}^{-1}$ of potassium chloride (54-00-72 $\mathrm{kg}$ of NPK ha-1) were applied. The experimental design was randomized blocks with four replications for both experiments.

In the first experiment the treatments were composed of a control without application and 
herbicides $\left(\mathrm{g} \mathrm{ha}^{-1}\right)$ applied isolated or in a tank mixture: diuron (250), diuron (500), s-metolachlor (480), s-metolachlor (960), imazethapyr (40), imazethapyr (80), diuron (250) + imazethapyr (40), diuron (500) + imazethapyr (80), diuron (250) + s-metolachlor (480), diuron (500) + s-metolachlor (960), imazethapyr (40) + s-metolachlor (480) and imazethapyr (80) + s-metolachlor (960).

The herbicides doses in the second experiment were adjusted based on herbicides that were selective in the first experiment and the possibility of association of diuron in postemergence. Thus, the second experiment was comprised of a factorial combination of eight herbicide treatments applied in preemergence with or without diuron $\left(500 \mathrm{~g} \mathrm{ha}^{-1}\right)$ in postemergence; there was also a control treatment without herbicides $(8 \times 2+1)$. The preemergence treatments used were herbicides in isolation or tank mixtures in doses in $\mathrm{g} \mathrm{ha}^{-1}$ of: diuron (500), diuron (750), s-metolachlor (480), s-metolachlor (720), diuron (500) + s-metolachlor (480), diuron $(500)+$ s-metolachlor (720), diuron $(750)+$ s-metolachlor (480) and diuron (750) + s-metolachlor (720). Postemergence diuron was applied 30 days after emergence (or 35 days after preemergence herbicide application) when the sesame plants had grown to a height of $25 \mathrm{~cm}$ to $30 \mathrm{~cm}$ and at the phenological growth stage V8-V10.

The herbicides were applied using a backpack sprayer pressurized with $\mathrm{CO}_{2}$, equipped with BD-110-02 flat spray nozzles, spaced $0.5 \mathrm{~m}$ apart and $40 \mathrm{~cm}$ high, emitting a spray volume equivalent to $200 \mathrm{~L} \mathrm{ha}^{-1}$. In both experiments, preemergence applications were performed one day after sesame sowing. The experimental units were maintained weed-free by manual weeding and a postemergence application of the narrow leaf herbicide haloxyfop-p-methyl $\left(62 \mathrm{~g} \mathrm{ha}^{-1}\right)$.

During the crop cycle, chemical pest control was performed as necessary, and disease management was done through preventive applications of a formulated mixture of trifloxystrobin + protioconazol $\left(75+87.5 \mathrm{~g} \mathrm{ha}^{-1}\right)$.

In the first experiment, visual evaluations of the sesame plants for intoxication were performed 10, 20 and 30 days after application (DAA) of herbicides in preemergence. In the second experiment, the evaluation for phytointoxication symptoms was made 15 days after application in postemergence. Phytointoxication levels were described as ranging from $0 \%$ which represents absence of injuries, to $100 \%$ which represents the death of plants (SBCPD, 1995). Approximately 110 days after sowing, when the first capsules started to open, plants from the two central rows of each plot were harvested; and sun-dried for 15 days. Subsequently, the grains were separated for weight and yield estimation. The data obtained in both tests were subjected to analysis of variance and the means were grouped using the Scott-Knott test $(\mathrm{P} \leq 0.05)$.

\section{Results and Discussion}

In the first experiment, the herbicide treatments resulted in different levels of phytotoxic damage to the sesame crop (Table 1). During the initial evaluation done 10 days after herbicide application (10 DAA), the symptoms of intoxication on the plants were more intense; nonetheless, they gradually reduced until 30 DAA. However, in some treatments, the 
symptoms did not abate the last evaluation at 30 DAA. The phytointoxication symptoms observed with the herbicides diuron and s-metolachlor were mild chloroses and reduced initial growth, whereas for the herbicide imazethapyr, marked reduction in growth.

The highest levels of intoxication in the sesame crop, with an average percentage of $71 \%$ at 10 DAA, were observed with the herbicide imazethapyr at doses of 40 and $80 \mathrm{~g} \mathrm{ha}^{-1}$ and in tank mixtures containing this herbicide. Intermediate phytointoxication levels (17 and 21\%) were caused by the herbicidal treatments s-metolachlor at a dose of $960 \mathrm{~g} \mathrm{ha}^{-1}$ and diuron + s-metolachlor $\left(500+960 \mathrm{~g} \mathrm{ha}^{-1}\right)$, respectively, which were greater than those caused by the other treatments involving these same molecules applied isolated or in a tank mixture. The herbicide diuron at $250 \mathrm{~g} \mathrm{ha}^{-1}$ was the only one that did not cause symptoms of phytointoxication, being statistically similar to the control treatment without herbicide. However, this dose is lower than the recommended for weed control (Rodrigues and Almeida, 2018).

For the phytointoxication assessment performed at 20 DAA, similar results to those obtained in the assessment performed at 10 DAA were observed. Treatments with the herbicides diuron and s-metolachlor in isolation and in tank mixtures of the two herbicides, in general, caused less symptoms of phytointoxication when compared to the first evaluation at 10 DAA, indicating recovery of sesame plants. However, treatments containing imazethapyr and its mixtures caused higher levels of phytointoxication than all other herbicides indicating the non-selectivity of this herbicide to the crop. As with the evaluation at 10 DAA, treatments with the herbicide s-metolachlor at $960 \mathrm{~g} \mathrm{ha}^{-1}$ led to higher levels of phytointoxication compared to the other treatments, in isolation or in tank mixture, even with the lowest dose of this molecule $\left(480 \mathrm{ha}^{1}\right)$. Grichar et al., (2018) found that the herbicide s-metolachlor $(1,430 \mathrm{~g}$ $\mathrm{ha}^{-1}$ ) when applied on clay soil resulted in $10 \%$ phytointoxication in sesame plants at 14 DAA, which reduced to $1 \%$ at 28 DAA. The phytointoxication levels observed with s-metolachlor in the present experiment were very high even with the lowest dose of the herbicide. It is possible that the sandy soil texture and the low organic matter content of the soil resulted in higher levels of intoxication in plants. Grichar et al., (2009) found that s-metolachlor at 1,430 $\mathrm{g} \mathrm{ha}^{-1}$ caused strong phytointoxication and a reduction of up to $70 \%$ in the stand in only one of the four study environments. 
Table 1. Phytointoxication levels $(\%)$ in sesame plants exposed to different herbicide treatments in preemergence at 10, 20 and 30 days after application and grain yield. Palmas, Tocantins, Brazil

\begin{tabular}{|c|c|c|c|c|c|}
\hline \multirow{3}{*}{ Preemergence herbicides } & \multirow{3}{*}{$\begin{array}{c}\text { Dose } \\
\left(\mathrm{g} \mathrm{ha}^{-1}\right)\end{array}$} & \multicolumn{3}{|c|}{ Phytointoxication (\%) } & \multirow{3}{*}{$\begin{array}{l}\text { Yield } \\
\left(\mathrm{kg} \mathrm{ha}^{-1}\right)\end{array}$} \\
\hline & & \multicolumn{3}{|c|}{ Days after application (DAA) } & \\
\hline & & 10 & 20 & 30 & \\
\hline Diuron & 250 & $0.0 \mathrm{~d}^{1}$ & $0.0 \mathrm{c}$ & $0.0 \mathrm{c}$ & $957 \mathrm{a}$ \\
\hline Diuron & 500 & $10.0 \mathrm{c}$ & $5.0 \mathrm{c}$ & $5.0 \mathrm{c}$ & $939 \mathrm{a}$ \\
\hline S-metolachlor & 480 & $10.0 \mathrm{c}$ & $2.5 \mathrm{c}$ & $2.5 \mathrm{c}$ & $885 \mathrm{a}$ \\
\hline S-metolachlor & 960 & $21.3 \mathrm{~b}$ & $16.3 \mathrm{~b}$ & $16.3 \mathrm{~b}$ & $947 \mathrm{a}$ \\
\hline Imazethapyr & 40 & $71.3 \mathrm{a}$ & $72.5 \mathrm{a}$ & $72.5 \mathrm{a}$ & $814 \mathrm{~b}$ \\
\hline Imazethapyr & 80 & $70.0 \mathrm{a}$ & $78.8 \mathrm{a}$ & $76.3 \mathrm{a}$ & $682 \mathrm{~b}$ \\
\hline Diuron + imazethapyr & $250+40$ & $71.3 \mathrm{a}$ & $75.0 \mathrm{a}$ & $68.8 \mathrm{a}$ & $678 \mathrm{~b}$ \\
\hline Diuron + imazethapyr & $500+80$ & $71.3 \mathrm{a}$ & $72.5 \mathrm{a}$ & $72.5 \mathrm{a}$ & $623 \mathrm{~b}$ \\
\hline Diuron + s-metolachlor & $250+480$ & $10.0 \mathrm{c}$ & $5.0 \mathrm{c}$ & $5.0 \mathrm{c}$ & $846 \mathrm{a}$ \\
\hline Diuron + s-metolachlor & $500+960$ & $17.5 \mathrm{~b}$ & $18.8 \mathrm{~b}$ & $18.8 \mathrm{~b}$ & $746 \mathrm{~b}$ \\
\hline Imazethapyr + s-metolachlor & $40+4$ & $70.0 \mathrm{a}$ & $83.8 \mathrm{a}$ & $73.8 \mathrm{a}$ & $781 \mathrm{~b}$ \\
\hline Ima & $80+96$ & $70.0 \mathrm{a}$ & $77.5 \mathrm{a}$ & $72.5 \mathrm{a}$ & $602 \mathrm{~b}$ \\
\hline Control without herbicide & 年 & $0.0 \mathrm{~d}$ & $0.0 \mathrm{c}$ & $0.0 \mathrm{c}$ & $920 \mathrm{a}$ \\
\hline $\mathrm{CV}(\%)$ & & 9.0 & 13.5 & 14.3 & 17.3 \\
\hline
\end{tabular}

${ }^{1}$ Means followed by the same letter in the column do not differ by the Scott-Knott test $(\mathrm{P} \leq 0.05)$.

In the evaluation performed at $30 \mathrm{DAA}$, similar phytointoxication results to those obtained in the evaluation at 20 DAA were observed. Plants treated with the herbicide imazethapyr continued to show symptoms of severe phyintoxication at 30 DAA, indicating that this herbicide is not selective for sesame crop. The other herbicides were selective for the cultivation although treatments with the herbicide s-metolachlor at $960 \mathrm{ha}^{-1}$ provided higher levels of phytointoxication, between $16 \%$ and $21 \%$.

The treatments with the herbicide imazethapyr showed lower yield than the others corroborating the effect observed during visual evaluations of phytointoxication. These results indicated that this herbicide is not selective to the sesame crop, even at a dose of $40 \mathrm{~g}$ ha $^{-1}$ (Table 1). Singh et al., (2018) also found that when isolated imazethapyr was applied isolated of $60 \mathrm{~g} \mathrm{ha}^{-1}$ in clay soil with $1.35 \% \mathrm{OM}$, it reduced the number of capsules per plant and the grain yield. However, Grichar et al., (2001a) and Kumar and Deepak (2017) found that imazethapyr $\left(40 \mathrm{~g} \mathrm{ha}^{-1}\right)$ did not cause yield reductions. These contradictory results are most likely due to the higher levels of clay in the soils where these studies were conducted.

The tank mixture composed of s-metolachlor + diuron $\left(960+500 \mathrm{~g} \mathrm{ha}^{-1}\right)$ also resulted in a lower yield when compared to the control treatment, or other treatments containing these same herbicides applied isolation or in a tank mixture. This yield reduction indicates that when the highest doses of these molecules are mixed, they are not selective for sesame crop. Thus, based on the greater visual phytointoxication found with s-metolachlor in treatments at a dose $960 \mathrm{~g} \mathrm{ha}^{-1}$, it is possible that the risk of damage to crop development is enhanced (given the yield reduction), when this herbicide is mixed with diuron at a dose of $500 \mathrm{~g} \mathrm{ha}^{-1}$. However, 250 and $500 \mathrm{~g} \mathrm{ha}^{-1}$ of the herbicide diuron and 480 and $960 \mathrm{~g} \mathrm{ha}^{-1}$ of the herbicide s-metolachlor applied in isolation, did not result in a reduction in sesame crop yield when compared to the control herbicides-free treatment. This selectivity of the herbicide diuron 
during preemergence has also been observed in other studies (Beltrão et al., 1991; Grichar et al., 2009; Imoloame et al., 2011; Wamduda et al., 2017; Grichar et al., 2018; Lins et al., 2020).

As was observed in the first experiment, the second experiment where the herbicides were applied in preemergence in isolation or in a tank mixture, resulted in different levels of phytotoxicity to sesame plant (Table 2). The symptoms of intoxication in plants were more intense in the initial evaluation at 10 DAA but gradually reduced by 30 DAA. There was no interaction between the herbicides applied in pre and postemergence for the evaluated variables, being presented only the isolated effects of the treatments.

At 10 DAA, preemergence treatments consisting of mixtures of the herbicides diuron and s-metolachlor, even at the lowest doses, resulted in the highest levels of phytointoxication in sesame crop ranging from $22 \%$ to $25 \%$ with significant differences observed from isolated diuron and s-metolachlor herbicide treatments. The herbicides treatments diuron $\left(750 \mathrm{~g} \mathrm{ha}^{-1}\right)$ and s-metolachlor $\left(720 \mathrm{~g} \mathrm{ha}^{-1}\right)$ caused higher levels of phytointoxication in the sesame cultivation when compared the lowest doses diuron and s-metolachlor $\left(500 \mathrm{~g} \mathrm{ha}^{-1}\right.$ and $480 \mathrm{~g}$ $\mathrm{ha}^{-1}$, respectively). Thus, even when applied in isolation, the herbicides diuron and s-metolachlor are less selective to the sesame crop at the highest doses.

During the visual assessment performed at 20 DAA, there was a reduction in phytointoxication symptoms when compared to the evaluation performed at 10 DAA. Mixtures of herbicides and diuron in isolation at the highest dose $\left(750 \mathrm{~g} \mathrm{ha}^{-1}\right)$ led to the highest levels of phytointoxication ranging from $15 \%$ to $19 \%$. The herbicide s-metolachlor at a dose of $720 \mathrm{~g} \mathrm{ha}^{-1}$ led to less phytointoxication than treatments with herbicide mixtures and higher than the s-metolachlor at a dose of $480 \mathrm{~g} \mathrm{ha}^{-1}$. The herbicide diuron at a dose of $500 \mathrm{~g}$ $\mathrm{ha}^{-1}$ did not cause symptoms of phytointoxication at 20 DAA, similar to the herbicide-free control treatment.

At 30 DAA, a maximum phytointoxication level of $11.3 \%$ was observed in the sesame plants indicating a gradual recovery and disappearance of symptoms even with treatments that caused the greatest injuries. The applications containing herbicides mixtures of diuron and s-metolachlor and with the highest doses of diuron $\left(750 \mathrm{~g} \mathrm{ha}^{-1}\right)$ led to the highest intoxication levels in the sesame cultivation ranging from $10.6 \%$ to $11.3 \%$. We did not observe symptoms of phytointoxication at 30 DAA with treatments containing s-metolachlor (480 and $720 \mathrm{~g} \mathrm{ha}^{-1}$ ) and diuron $\left(500 \mathrm{~g} \mathrm{ha}^{-1}\right)$ indicating the recovery of the crop from the initial symptoms. 


\section{$\triangle$ Macrothink}

Table 2. Phytointoxication (\%) levels, plant height and grain yield of the sesame plants exposed to different herbicide treatments in preemergence at 10, 20 and 30 days after application and diuron in postemergence at 15 days after application, Palmas, Tocantins, Brazil

\begin{tabular}{|c|c|c|c|c|c|c|c|}
\hline \multirow{3}{*}{$\begin{array}{l}\text { Preemergence } \\
\text { herbicides }\end{array}$} & & \multirow{3}{*}{$\begin{array}{l}\text { Dose } \\
\left(\mathrm{g} \mathrm{ha}^{-1}\right)\end{array}$} & \multicolumn{3}{|c|}{ Phytointoxication (\%) } & \multirow{3}{*}{$\begin{array}{l}\text { Plant } \\
\text { height } \\
\text { (m) }\end{array}$} & \multirow{3}{*}{$\begin{array}{r}\text { Yield } \\
\left(\mathrm{kg} \mathrm{ha}^{-1}\right)\end{array}$} \\
\hline & & & \multicolumn{3}{|c|}{ Days after application (DAA) } & & \\
\hline & & & 10 & 20 & 30 & & \\
\hline Diuron & & 500 & $10.0 \mathrm{c}^{1}$ & $0.0 \mathrm{~d}$ & $0.0 \mathrm{~b}$ & $1.53^{\mathrm{ns}}$ & $743^{\mathrm{ns}}$ \\
\hline Diuron & & 750 & $18.1 \mathrm{~b}$ & $15.0 \mathrm{a}$ & $10.0 \mathrm{a}$ & 1.43 & 725 \\
\hline S-metolachlor & & 480 & $13.1 \mathrm{c}$ & $7.9 \mathrm{c}$ & $0.0 \mathrm{~b}$ & 1.49 & 731 \\
\hline S-metolachlor & & 720 & $15.6 \mathrm{~b}$ & $10.9 \mathrm{~b}$ & $0.0 \mathrm{~b}$ & 1.43 & 774 \\
\hline Diuron & + & & & & & & \\
\hline s-metolachlor & & $500+480$ & $22.5 \mathrm{a}$ & $16.9 \mathrm{a}$ & $10.6 \mathrm{a}$ & 1.44 & 636 \\
\hline Diuron & + & & & & & & \\
\hline s-metolachlor & & $500+720$ & $25.6 \mathrm{a}$ & $18.8 \mathrm{a}$ & $10.0 \mathrm{a}$ & 1.49 & 734 \\
\hline $\begin{array}{l}\text { Diuron } \\
\text { s-metolachlor }\end{array}$ & + & $750+480$ & $24.4 \mathrm{a}$ & $16.3 \mathrm{a}$ & $11.3 \mathrm{a}$ & 1.45 & 641 \\
\hline Diuron & + & & & & & & \\
\hline s-metolachlor & & $750+720$ & $23.1 \mathrm{a}$ & $15.6 \mathrm{a}$ & $10.6 \mathrm{a}$ & 1.49 & 680 \\
\hline Without herbicide & & - & $0.0 \mathrm{~d}$ & $0.0 \mathrm{~d}$ & $0.0 \mathrm{~b}$ & 1.40 & 716 \\
\hline \multicolumn{8}{|c|}{ Postemergence Herbicide } \\
\hline \multicolumn{8}{|l|}{ Without } \\
\hline Postemergence & & - & - & - & - & $1.44^{\mathrm{ns}}$ & $706^{\mathrm{ns}}$ \\
\hline Diuron & & 500 & - & - & - & 1.49 & 711 \\
\hline $\mathrm{CV}(\%)$ & & & 18.5 & 34.5 & 18.0 & 7.5 & 15.3 \\
\hline
\end{tabular}

${ }^{1}$ Means followed by the same letter in the column do not differ by the Scott-Knott test $(\mathrm{P} \leq 0.05) .{ }^{\mathrm{ns}}$ Averages do not differ by F-test $(\mathrm{P} \leq 0.05)$.

When comparing the above results to those of the first experiment in which a maximum dose of $960 \mathrm{~g} \mathrm{ha}^{-1}$ of s-metolachlor was used, phytointoxication symptoms at a dose of $720 \mathrm{~g} \mathrm{ha}^{-1}$ are lesser than $960 \mathrm{~g} \mathrm{ha}^{-1}$ of s-metolachlor treatment. Therefore, even when used in tank mixture with the herbicide diuron, this s-metolachlor dose is a more selective dose for sesame cultivation in soils with low clay content. The selectivity of the herbicide diuron (Beltrão et al., 2001; Grichar et al., 2009; Wamduda et al., 2017) and s-metolachlor (Grichar et al., 2009; Sperry et al., 2016) has already been reported in other studies and is dependent on the herbicide dose and class of soil. The current study illustrated that in medium-textured soil, the preemergence application of the herbicides diuron and s-metolachlor in a tank mixture is selective to the sesame crop provided that s-metolachlor is used at a dose lower than or equal to $720 \mathrm{~g} \mathrm{ha}^{-1}$. As regards diuron, using it in preemergence to a maximum dose of $750 \mathrm{~g} \mathrm{ha}^{-1}$ was selective in medium-textured soil. The texture of the soil plays an important role in the preemergence dose of herbicides tolerated by the crop. Wamduda et al., (2017) reported that the sesame crop tolerated the herbicide diuron to a dose of $500 \mathrm{~g} \mathrm{ha}^{-1}$ in sandy soil $(83 \%$ sand). On the other hand, Grichar et al., (2009) verified the selectivity of diuron at a dose of $1,112 \mathrm{~g} \mathrm{ha}^{-1}$ in soils containing a clay content between $20 \%$ and $40 \%$.

There were no symptoms of intoxication observed in the sesame cultivation after application of the herbicide diuron at a dose of $500 \mathrm{~g} \mathrm{ha}^{-1}$ in postemergence so these data were not 
presented. These results indicate that this herbicide is selective to the sesame crop when applied 35 days after the application of the herbicides during preemergence at the phenological stage V8-V10. Grichar et al., (2018) also showed that application of diuron $\left(1,120 \mathrm{~g} \mathrm{ha}^{-1}\right) 21$ days after sowing of sesame did not cause symptoms of sesame intoxication in two of three tested sites. The same authors found higher levels of initial phytointoxication in earlier applications of diuron 14 and 21 days after sowing. However, at the end of the cycle, the only mild phytointoxication symptoms were observed indicating recovery of the sesame plants. The selectivity of diuron in postemergence controls eudicot weeds that were not controlled by the herbicides applied in preemergence. In this context, the predominant absorption of diuron by the roots and its residual effect, and its' half-life of 90 days (Rodrigues and Almeida, 2018), allows it to prolong its' control of the emergence of a wide number of species during the crop cycle. The potential of using diuron for sesame cultivation is favored by its postemergence herbicidal action on the soybean (Fayez, 2000); a trait that allows the control of volunteer plants of this species when sesame is grown in succession to the soybean, including cultivars resistant to glyphosate (Dan et al., 2011; Lima et al., 2011), 2,4-D, dicamba and tolerant to the herbicides of the chemical group of sulfonylureas, since diuron is a photosystem-II inhibiting herbicide.

The height of the sesame plants and grain yield at the end of the cycle were neither influenced by the application of herbicides in preemergence, nor by the application of diuron $\left(500 \mathrm{~g} \mathrm{ha}^{-1}\right)$ in postemergence. In addition, there was no interaction between the two factors. These results indicate that the herbicides diuron and s-metolachlor applied in isolation or in a tank mixture to a maximum dose of $750 \mathrm{~g} \mathrm{ha}^{-1}$ and $720 \mathrm{~g} \mathrm{ha}^{-1}$, respectively, are selective to the sesame crop and do not negatively affect grain yield. Even sesame plants exposed to treatments that caused higher levels of phytointoxication recovered and their height and yield were unaffected. Similarly, Grichar et al., (2018) did not find a reduction in sesame yield when using the herbicide diuron at a dose of $1,120 \mathrm{~g} \mathrm{ha}^{-1}$ in postemergence 14, 21 and 28 days after sowing.

Generally, our results indicate that in medium-textured soil, the herbicides diuron and s-metolachlor applied in preemergence in isolation or in a tank mixture, are selective to the sesame crop. The herbicide diuron is selective to a maximum dose of $750 \mathrm{~g} \mathrm{ha}^{-1}$, while s-metolachlor to a maximum dose of $720 \mathrm{~g} \mathrm{ha}^{-1}$. These two herbicides control a broad spectrum of weeds in preemergence; which is important for the crop initial development in the absence of competition. Diuron $\left(500 \mathrm{~g} \mathrm{ha}^{-1}\right)$ applied in postemergence was also selective for the sesame crop. Nonetheless, further studies are needed to determine this crop's species optimum herbicide dose and the appropriate phenological stage for herbicide selectivity.

\section{Conclusions}

The herbicides diuron and s-metolachlor applied in preemergence in isolation or in a tank mixture, are selective to the sesame crop up to the doses of $750 \mathrm{~g} \mathrm{ha}^{-1}$ and $720 \mathrm{~g} \mathrm{ha}^{-1}$, respectively. Additionally, the same herbicide applied in association with diuron at a dose of $500 \mathrm{~g} \mathrm{ha}^{-1}$ in postemergence are selective for sesame crop. 


\section{References}

Ambika, M., \& Sundari, A. (2019). Weed management in irrigated sesame (Sesamum indicum L.). World Scientific News, 131(1), 272-278.

Ayesha, F., Duary, B., Singh, V. K., \& Basant, K. (2020). Effect of integrated use of competitive cultivars, herbicide and mulch on weed dynamics, weed-control efficiency, weed index and yield of summer sesame (Sesamum indicum). Indian Journal of Agronomy, 65(2), 238-241.

Beltrão, N. E. M., Vieira, D. J., Nóbrega, L. B., \& Santos, J. W. (1991). Adubação, cultivar e controle de plantas daninhas na cultura do gergelim. Pesquisa Agropecuária Brasileira, Brasília, 26(5), 605-611.

Bereta, S. F., Nohatto, M. A., Rosa, E. F. F., Kaseker, J. F., Santos, M. C., \& Witter, A. P. W. (2021). Seletividade de herbicidas em pós-emergência e controle de plantas daninhas no gergelim. Agrarian, 14(51), 27-35. https://doi.org/10.30612/agrarian.v14i51.11569

Dan, H. A., Procópio, S. O., Barroso, A. L. L., Dan, L. G. M., Oliveira Neto, A. M., \& Guerra, N. (2011). Controle de plantas voluntárias de soja com herbicidas utilizados em milho. $\begin{array}{llll}\text { Revista Brasileira de } & \text { Ciências }\end{array}$ https://doi.org/10.5039/agraria.v6i2a1032

EMBRAPA-Empresa Brasileira de Pesquisa Agropecuária. (2018). Sistema Brasileiro de Classificação de Solos. 5. Ed. Rio de Janeiro: Embrapa Solos. 365p.

Fayez, K. A. (2000). Action of photosynthetic diuron herbicide on cell organelles and biochemical constituents of the leaves of two soybean cultivars. Pesticide Biochemistry and Physiology, 66, 105-115. https://doi.org/10.1006/pest.1999.2459

Grichar, W. J., Dotray, P. A., \& Langham, D. R. (2009). Sesame (Sesamum indicum L.) response to preemergence herbicides. Crop Protection, 28, 928-933. https://doi.org/10.1016/j.cropro.2009.07.013

Grichar, W. J., Dotray, P. A., \& Langham, D. R. (2014). Sesame tolerance to herbicides applied postemergence-directed. American Journal of Experimental Agriculture, 4(2), 162-170. https://doi.org/10.9734/AJEA/2014/6644

Grichar, W. J., Dotray, P. A., \& Langham, D. R. (2011). Weed control and the use of herbicides in sesame production. In: Soloneski, S. \& Larramendy, M. L. Herbicides, Theory and Applications (pp. 41-72).

Grichar, W. J., \& Dotray, P. (2007). Weed control and sesame (Sesamum indicum L.) response to preplant incorporated herbicides and method of incorporation. Crop Protection, 26, 1826-1830. https://doi.org/10.1016/j.cropro.2007.03.017

Grichar, W. J., Rose, J. J., Dotray, P. A., Baughman, T. A., Langham, D. R., Werner, K., \& Bagavathiannan, M. (2018). Response of sesame to selected herbicides applied early in the growing season. International Journal of Agronomy, 2018, 1-11. 
https://doi.org/10.1155/2018/9373721

Grichar, W. J., Sestak, D. C., Brewer, K. D., Besler, B. A., Stichler, C. R., \& Smith, D. T. (2001a). Sesame (Sesamum indicum L.) tolerance and weed control with soil-applied herbicides. Crop Protection, 20, 389-394. https://doi.org/10.1016/S0261-2194(00)00147-2

Grichar, W. J., Sestak, D. C., Brewer, K. D., Besler, B. A., Stichler, C. R., \& Smith, D.T. (2001b). Sesame (Sesamum indicum L.) tolerance with various postemergence herbicides. Crop Protection, 20, 685-689. https://doi.org/10.1016/S0261-2194(01)00036-9

Hossain, M. S., Rahman, A, Salim, M., Hoque, M., Hasan, A. K. (2020). Response of selected sesame varieties to different weed management practices. Fundamental and Applied Agriculture, 5(2), 167-175. http://dx.doi.org/10.5455/faa.80257

Imoloame, E. O., Joshua, S. D., \& Gworgwor, N. A. (2011). Effect of pre-emergence herbicides on weed infestation and productivity of sesame (Sesamum indicum L.) in the Sudan savanna zone of Nigeria. Journal of Agricultural Biotechnology and Sustainable Development, 3(2), 19-27.

Kumar, M., \& Deepak, S. R. K. (2017). Weed control in custard apple-sesame agrihorticulture system. Agricultural Research Journal, 54(1), 139-140. https://doi.org/10.5958/2395-146X.2017.00028.X

Lima, D. B. C., Silva, A. G., Procópio, S. O., Barroso, A. L. L., \& Dan, H. A. (2011). Controle químico de plantas voluntárias de soja Roundup Ready® em diferentes estádios de desenvolvimento. Revista Caatinga, 24(3), 64-70.

Lins, H. A., Barros Júnior, A. P., Silva, D. V., Souza, M. F., Freitas, M. A. M., Soares, E. B., Porto, M. A. F., Mesquita, H. C., \& Oliveira, F. S. (2020). Effectivity and selectivity of herbicides applied in pre-emergence in the sesame (Sesamum indicum L.) crop. Revista de la Facultad de Ciencias Agrarias, 52(2), 325-336.

Lins, H. A., Souza, M. F., Albuquerque, J. R. T., Santos, M. G., Barros Júnior, A. P., \& Silva, D. V. (2019). Weed interference periods in sesame crop. Ciência e Agrotecnologia, 43, 1-10. https://doi.org/10.1590/1413-7054201943000819

Mane, S. V., Kanade, V. M., Shendage, G. B., Sarawale, P. P., \& Shetye, V. N. (2017). Weed management in sesamum (Sesamum indicum L.) grown under coastal region of Maharashtra. Journal of the Indian Society of Coastal Agricultural Research, 35(1), 31-33.

Murimwa, J. C., Rugare, J. T., Mabasa, S., \& Mandumbu, R. (2019). Allelopathic effects of aqueous extracts of sorghum (Sorghum bicolor L. Moench) on the early seedling growth of sesame (Sesamum indicum L.) varieties and selected weeds. International Journal of Agronomy, 2019 (1), 1-12, https://doi.org/10.1155/2019/5494756

Rodrigues, B. N., \& Almeida, F. S. (2018). Guia de Herbicidas, 7 ed. Londrina: Edição dos autores.

Singh, R., Dibakar, G., Dubey, R. P., \& Singh, V. P. (2018). Weed control in sesame with 


\section{Macrothink}

Journal of Agricultural Studies

ISSN 2166-0379

2021, Vol. 9, No. 4

pre-emergence herbicides. Indian Journal of Weed Science, 50(1), 91-93. https://doi.org/10.5958/0974-8164.2018.00022.9

Sociedade Brasileira Da Ciência Das Plantas Daninhas - SBCPD. (1995). Procedimentos para instalação, avaliação e análise de experimentos com herbicidas. Londrina: SBCPD.

Sperry, B. P., Ferrel, J. A., Leon, R. G., Rowland, D. L., \& Mulvaney, M. J. (2016). Influence of planting depth and application timing on s-metolachlor injury in sesame (Sesamum indicum L.). Weed Technology, 30(4), 958-964. https://doi.org/10.1614/WT-D-16-00081.1

Sperry, B. P., Ferrel, J. A., Leon, R. G., Rowland, D. L., Mulvaney, M. J., \& Dias, J. L. C. S. (2017). Sesame tolerance to preplant applications of 2,4-D and dicamba. Weed Technology, 31, 590-598. https://doi.org/10.1017/wet.2017.37

Wamduda, D. K. K., Kwaga, Y. M., Toungos, M. D., \& Nedamanya, B. (2017). Efficacy of butachlor and diuron in the control of weeds in sesame (Sesamum indicum L.) in mubi, northern guinea savanna zone, Nigeria. International Journal of Trend in Research and Development, 4(2), 327-333.

\section{Copyright Disclaimer}

Copyright for this article is retained by the author(s), with first publication rights granted to the journal.

This is an open-access article distributed under the terms and conditions of the Creative Commons Attribution license (http://creativecommons.org/licenses/by/4.0/). 